\title{
Breaking the Rules: Innovation and Narrative Strategies in Sandra Cisneros' The House on Mango Street and Ana Castillo's The Mixquiahuala Letters
}

\section{Carmen Haydée Rivera University of Puerto Rico}

Conventional approaches to literary genres conspicuously imply definition and classification. From the very beginning of our incursions into the literary world we learn to identify and differentiate a poem from a play, a short story from a novel. As readers we classify each written work into one of these neatly defined literary genres by following basic guidelines. Either we classify according to the structure of the work (stanza; stage direction/dialogue; narrative) or the length (short story; novelette; novel). What happens though when a reader encounters a work of considerable length made up of individual short pieces or vignettes that include rhythm and rhyme and is framed by an underlying, unifying story line linking the vignettes together? Is it a novel or a collection of short stories? Why does it sound and, at times, look like a poem? To further complicate classifications, what happens when a reader comes across an epistolary format with instructions on which letters to read first: letters made up of one-word lines, poetic stanzas, or italicized stream of consciousness; letters that narrate the history of two women's friendship? Is this a novel or a mere collection of letters? 
To encounter these two formats is to do away with conventional classifications and divisions but not to do away with the work. To come across these unconventional formats is to accept the challenge set forth by two contemporary Chicana writers, Sandra Cisneros and Ana Castillo, whose works defy literary classifications. The juxtaposed and overlapping literary modes found in The House on Mango Street and The Mixquiahuala Letters enable both writers to come to terms with their identity as Mexican American women straddling two countries and two cultures. By incorporating Hispanic dialect, impressionistic metaphor, social commentary, as well as by addressing such issues as poverty, cultural suppression, and gender roles, Cisneros and Castillo reveal the fears and doubts unique to their experience as Chicanas and their relationship to their community. Through writing Cisneros and Castillo also communicate the possibility of overcoming obstacles brought about by stereotypical images of women and the inevitable clash between Mexican and American cultures. The fragmented, non-linear, unconventional structure of their work provides a means for expressing and reconciling their multi-faceted life experience.

From its first publication in 1983 by Arte Publico Press, Cisneros' The House on Mango Street posed a problem for critics and their reviews. Gary Soto described the work as "poetic prose . . . but foremost a story telling" (144). Penelope Mesic saw it as "vignettes of autobiographical fiction written in a loose and deliberately simple style, halfway between a prose poem and the awkwardness of semiliteracy" (281). Cisneros herself pointed out in an interview that she "wanted to write a collection which could be read at any random point without having any knowledge of what came before or after. Or that could be read as a series to tell one big story. I wanted stories like poems, compact and lyrical and ending with reverberation" (77). Cisneros creates the voice of the adolescent Esperanza Cordero as a poetic persona and ponders the sense of confusion brought about by growing up with Mexican customs and traditions in American society.

Three main issues preoccupy Esperanza as the narrator from whose perspective the events of the story unfold: her identity, her surroundings, and her emotional release through writing. Early 


\section{Ethnic Studies Review Volume 26: 1}

in the work Esperanza expresses her discontent with her name in defining her identity:

In English my name means hope. In Spanish it means too many letters. It means sadness, it means waiting. It was my great-grandmother's name and now it is mine. She looked out the window all her life, the way so many women sit their sadness on an elbow .... I have inherited her name, but I don't want to inherit her place by the window.

With the story of Esperanza's naming Cisneros points to one of the essential cultural traits associated with women in the Mexican community: the encoded lesson of enduring submissiveness passed down from one generation to another. Esperanza describes her great-grandmother as "a wild horse of a woman, so wild she wouldn't marry" yet who was forcibly carried away by her great-grandfather "like a fancy chandelier" (10). While remembering her great-grandmother's sadness, Esperanza is able to deconstruct the encoded lesson related to her name and revise its content. Though she would have liked to have known her great-grandmother, Esperanza does not "want to inherit her place by the window" (11). Consequently Esperanza searches for an identity outside of the confines of a dominant patriarchy that only offers her "sadness" and "waiting." The section titled "My Name" ends with her desire to adopt a new name in an attempt to change her own destiny and move away from the constraints inherent in the Spanish meaning of Esperanza:

I would like to baptize myself under a new name, a

name more like the real me, the one nobody sees.

Esperanza as Lisandra or Maritza or Zeze the X. Yes.

Zeze the $X$ will do. (11)

Her desire to baptize herself under a different name reflects her resistance to cultural imposition and the suppression of female self-identity. This rebellious attitude characterizes Esperanza's increasingly assertive and non-conformist stance throughout the work.

Another key element of concern for Esperanza is the space she inhabits. Though she longs for a room of her own and a house she can be proud of, Esperanza's family constantly moves from one dilapidated neighborhood to another. Even when the 
father finally buys a house, it is far from the one "Papa talked about when he held a lottery ticket" (4). Esperanza often links the houses she has lived in with a sense of degradation as if the tight steps, crumbling bricks, and small windows were emblematic of her impoverished condition. Bonnie TuSmith accurately points out the situation:

The house on Mango Street can be seen as an 'ethnic sign' that can easily close off the future for the young protagonist .... . If she accepts it as her lot in life, then she is conforming to the dominant culture's definition of who she is. Her refusal to accept this house as home, however, indicates that she has the capacity to look beyond her present conditions and continue to dream (161).

Esperanza's dreams and illusion of a real home come forth in one of the most poetically evocative sections of the work in which Cisneros combines rhythm, rhyme, alliteration, and similes to reflect Esperanza's yearning for her own space:

A house of my own. Not a flat. Not an apartment in back. Not a daddy's. A house all my own. With my porch and my pillow, my pretty purple petunias. My books and my stories .... Only a house quiet as snow, a space for myself to go, clean as paper before the poem. (108)

Unable to adapt to the harsh environment that surrounds her, Esperanza also dreams of leaving Mango Street behind, of escaping the neighborhood's limiting powers. Esperanza's critical eye notices all too well the fate of the women who decide to stay within the confines of Mango Street. They either choose marriage over education (Sally), become abandoned mothers with a house full of children (Rosa Vargas), feel out of place and grieve over memories of a previous home (Mamacita), remain locked in an apartment by a jealous husband (Rafaela), or end up as victims of repeated domestic violence (Minerva). Yet it is precisely through women that Esperanza begins to understand and come to terms with her role within her community. One of the enigmatic Three Sisters, who appears almost at the end of the work, reminds Esperanza of her mission:

When you leave you must remember to come back for 


\section{Ethnic Studies Review Volume 26: 1}

the others. A circle, understand? You will always be Esperanza. You will always be Mango Street. You can't erase what you know. You can't forget who you are. You must remember to come back. For the ones who cannot leave as easily as you. You will remember? She asked as if she was telling me. (105)

At this point, the English meaning of Esperanza's name reveals itself: she symbolizes hope. As a Chicana who rejects the stereotypical roles of submission, suffering, and victimization, Esperanza represents the possibility of change and hope for a different future; nevertheless she does not totally reject her culture or her heritage. Jean Wyatt points out that "viewed from the perspective of the collection as a whole, the stories can be seen as parts of a dialectical process of negotiating with cultural icons that are both inalienable parts of oneself and limitations of one's potential as a woman" (266). Esperanza internalizes the Three Sisters' message and will return, time and again, through her own storytelling and writing, to Mango Street. She combines her own story with the stories of the other women on Mango Street. Esperanza's storytelling takes on characteristics of a communal narrative in which each component/story is essential to the other. Esperanza can easily become Marin, Mamacita, Sally, or Rafaela. Her determination to follow a different route, akin to Alicia's goal of attaining an education, prevents her from falling into a recurrent pattern of disenfranchised and suffering women. The Three Sisters' message, in a way, becomes a metaphor for the artist/writer's responsibility to his/her community. Even if Esperanza leaves Mango Street behind, the people whom she met and the experiences shared with them will always form a part of her memory and of who she is. It is this memory of past experience that infuses her writing.

Emotional release through writing becomes, consequently, the unifying force behind the narrative. In the last section of the work Cisneros places Esperanza within a circular framework by ending where she begins: telling a story. Yet Esperanza also puts stories "down on paper" (110) which reminds the reader of Aunt Lupe's prophetic words: "You must remember to keep writing, Esperanza. You must keep writing. It will keep you free. And I said yes" (61). 
Esperanza echoes Aunt Lupe's advice in the work's final section and she also reveals how seriously she has taken the Three Sisters' advice:

I write it down and Mango says good-bye sometimes. She does not hold me with both arms. She sets me free .... One day I will say good-bye to Mango. I am too strong for her to keep me here forever. They [friends and neighbors] will not know that I have gone away to come back. For the ones I left behind. For the ones who cannot out. (110)

Esperanza transcends her social condition through writing yet what she writes about reinforces her solidarity with her people, especially the women, of Mango Street. TuSmith remarks, "While Mango Street does not endorse certain culturally sanctioned patterns of behavior-namely, those that are restrictive and abusive to women-its orientation and message are clearly communal" (167). Consequently Esperanza can reject stereotypical roles imposed on women by patriarchy yet at the same time feel solidarity with the women caught in such restrictive roles. Lodging this realization in a young Chicana's seemingly naïve perceptions allows Cisneros as author to expose and critique the cultural, social, and economic subordination of confined and abused women. With a collection of vignettes characterized by their poetic and lyrical quality, Sandra Cisneros manages to create a distinctive narrative discourse that empowers the female protagonist to define what she thinks is best for her instead of what her culture dictates. In this sense the unconventional structure fits the unorthodox account of a young Chicana's coming of age story. The work also captures the dialectic between self/writer and community. Esperanza finds her literary voice through her own cultural awareness and experience with other Chicanas. The self-empowerment she seeks through writing coalesces with her commitment to community and with her promise to pass that power on to other women.

Similar to Cisneros's work, unconventional narrative structure is also evident from the very first address to the reader in Ana Castillo's The Mixquiahuala Letters. Before the initial letter, Castillo declares:

It is the author's duty to alert the reader that this is not 


\section{Ethnic Studies Review Volume 26: 1}

a book to be read in the usual sequence. All letters are numbered to aid in any one of the author's proposed options.

Castillo's instructions give way to three possible readings: for the conformist (29 letters), for the cynic (32 letters), and for the Quixotic (34 letters). As a whole the work only contains forty letters. Some letters repeat themselves in two or the three categories while other letters are left out from any of the three categories. Through the device of letters exchanged over a ten-year period between Teresa, a California poet, and Alicia, a New York artist, Castillo explores the changing roles of women in the United States during the 1970s and 1980s. Castillo also reveals the negative reactions many conservative Hispanic and Anglo American men felt toward female liberation during this era. Patricia De La Fuente describes the novel as "a provocative examination of the relationship between the sexes; a far ranging social and cultural expose" (63). Norma Alarçon, on the other hand, sees the novel as "Castillo's experimentations with shifting pronouns and appropriative techniques for the purpose of exploring the romantic/erotic" and suggests that the female narrator "is betrayed by a cultural fabric that presses its images of her upon her" (64). Culture, heritage, gender roles, and a reaction to stereotypical images are once again in conflict in Castillo's work as they are in Cisneros' writing.

The three primary concerns discussed in Cisneros' The House on Mango Street (identity, surroundings, and writing) can also be traced in Castillo's The Mixquiahuala Letters, yet, unlike the adolescent Esperanza Cordero, the narrator/letter writer, Teresa, is a thirty-year old Chicana who has had her share of experience in both the Mexican and North American cultural contexts. In Letter One Teresa comments:

At thirty, i [sic] feel like I [sic] am beginning a new phase in life: adulthood. The twenties were a mere continuation of adolescence. But as grown-up life begins, society wants to make one believe that thirty is the beginning of the end. (21)

Though she is much older than Esperanza, Teresa is still struggling with unresolved issues she carries from her past. Alicia, the narratee and receiver of the letters, is an important part of this 
past since she has shared pivotal moments in Teresa's life. Teresa's continuous search for identity, for a response to clarify hidden doubts concerning her female self and sense of worth, also becomes Alicia's search from the very moment they meet in Mexico City. Hector Torres comments that "the Letters subvert the patriarchal desire to dominate identity, to keep it linear, unidimensional, bound to a logocentric address. In this view the Letters become a space in which Teresa and Alicia share an always never simple identity, in opposition to patriarchal discourse" (129). Since Teresa and Alicia move in and out of two countries and two cultures, they search for a sense of identity that can capture both their realities as Mexican-American and Anglo-Spanish, yet at times their identity is determined for them by others based on the fact that they are two women traveling alone in Mexico without a male escort. This dilemma appears from the very first letter and reappears in Letter Eighteen and Letter Nineteen. When Teresa and Alicia return to Mexico after a five-year absence, the same circumstances await them as they travel through the country. In Letter Nineteen Teresa comments:

... we have abruptly appeared in Mexico as two snags in its pattern. Society could do no more than snip at us. How revolting we were, susceptible to ridicule, abuse, disrespect. We would have hoped for respect as human beings, but the only respect granted a woman is that which a gentleman bestows upon the lady. Clearly, we were no ladies. What was our greatest transgression? We traveled alone. (65-66)

(The assumption here is that neither served as a legitimate companion for the other). Along with this assumption comes a host of other preconceived ideas that relate to gender roles and female sexuality. Men, in particular, see them as free and willing targets of their (the men's) own sexual desires. This is certainly the case with the prosperous Veracruz businessman, Ahmad, who invites them to visit his mansion (Letter Eighteen, Letter Twenty-One, Letter Twenty-Two). Even the open-minded Sergio Zamora, Teresa's suitor, is eventually overpowered by his ingrained chauvinism, consequently leading to their broken engagement.

In spite of the reception and treatment, Teresa and Alicia 


\section{Ethnic Studies Review Volume 26: 1}

remain bonded and confront each obstacle encountered in their path. Teresa refers to Alicia as "my sister, companion, my friend" and regards their relationship as an "allegiance in good faith passion bound by uterine comprehension. In sisterhood. In solidarity. A strong embrace. Always. We were not to be separated" (24). Critic Erlinda Gonzalez-Berry sees the close relationship between Teresa and Alicia in psychoanalytic terms and proposes the argument that "Alicia is Teresa's double, the split occurring on her first trip to Mexico. Alicia would thus represent Teresa's 'Anglo' self, a self that often emerges when we come in contact with Mexicans and realize that they view us as 'pochos'" (123). Yet neither the Mexicans nor the Americans treat the women kindly. Each society presents its own set of problems that the women must eventually confront. This leaves them with an unresolved sense of identity despite their strong and independent characters. Their discontent also surfaces as a product of failed relationships with men and their emotional depression and frustration.

There is only one place depicted in the novel where both women find a peaceful and alluring atmosphere. This place becomes the sole reason why they return to Mexico after a fiveyear absence. During their enrollment at a North American institution in Mexico City that turns out to be "a notch above fraudulent status" (24), Teresa and Alicia spend a weekend visit in Mixquiahuala, "a Pre-Conquest village of obscurity, neglectful of progress, electricity notwithstanding" (25). In Letter Three Teresa describes that, amidst Toltec ruins and monolithic statues, a rugged hike took them to the edge of a muddy river where they saw the native inhabitants:

There, native women washed, beat clothes against polished stones; Indian [sic] children with streaks of blond in their hair bathed and splashed carefree. At the arch of the crude bridge, a rustic cross tied with the vines of trees, marked abrupt death. (26)

The simplicity and carefree nature of this environment immediately contrasts with the crowded and aggressive ambiance of Mexico City. Castillo juxtaposes the description of Mixquiahuala with the illusion that Teresa is part of the foliage. The site relates to in Teresa's words "the exotic tinge of yellow and red in my 
complexion, the hint of an accent in my baroque speech, and most of all, the indiscernible origin of my being" (26). An interesting aspect of the Mixquiahuala description is the absence of male figures that seems to suggest that this peaceful, idyllic environment can only exist outside the confines of patriarchal structures. This would justify, in part, its appeal to Teresa and Alicia who conserve the memories of the place intact long after having been there.

The name Mixquiahuala never appears again in any other letter; nonetheless it appears as the novel's title. Consequently there is an intricate relation between the name and the process of writing. The question of narrative strategy comes to mind when reviewing this relationship. Raymund Paredes addresses the issue as he comments that "the letters that constitute the novel are written by Teresa to her friend and traveling companion but often rehearse the physical facts of the women's experience together. What is not clear is why anyone would write such elaborate letters simply to retell, without analysis, what the recipient already knows" (Torres 128). Yet the process of letter writing involves much more than just a simple retelling. First of all, the writing establishes a connection between the two women who are separated by physical distance but who will not allow this distance to weaken or obliterate their friendship. Letter Thirty-One and Letter Thirty-Seven, among others, are examples of how they keep their communication going despite the fact that they have not seen each other in a long period of time. Since Teresa is the poet, the writer, it makes sense for the letters to come from her. Another important aspect of the letter writing is that, through the process of reminiscing and recreating pivotal moments of self-awareness and self-growth shared by the two women, Teresa experiences an emotional release through writing similar to Esperanza Cordero's story telling/writing. Teresa comes to terms with many issues that have hitherto stunted her growth (insecurity, weakness, dependence, disillusion, indecision). Although she does not claim to have resolved every issue, she at least transcends them. By the end of the novel (and the letter-writing process), Teresa emerges as a different person, one much more in control of her life and her mental/emotional state. The fact that Alicia functions as narratee to Teresa's letters binds 


\section{Ethnic Studies Review Volume 26: 1}

the women even more in a relationship of mutual love and understanding.

The question, then, is not why anyone would write such elaborate letters but why the writer would call them the Mixquiahuala letters. Mixquiahuala takes on a symbolic significance. Out of all the locations mentioned in the novel, Mixquiahuala is the only place where Teresa and Alicia find a lifestyle in communion with nature, a serene environment, noble for its simplicity. In this sense the surroundings represent for the women moments of shared freedom from disturbing thoughts or emotions, even moments of pleasure as they later recall Teresa's ruined tennis shoes, muddy slacks, and slip down the riverbank. Mixquiahuala, in Torres' analysis, embodies "everything that is worth saving in their relationship. ..., the core of their experience together, what has allowed them to be allies" (137). Mixquiahuala, then, represents a special place for Teresa and Alicia, evoked through their memories and effectively alluded to in the novel's title.

At the authorial level Castillo deliberately strays from conventional narrative techniques in the framing of these letters. She experiments and plays with beginnings, endings, line spaces, paragraph structures, capitalization, and often includes verse as part of her narrative. The letters are at times anecdotal. Yet at other times the writing sways into the territory of stream of consciousness (usually italicized) depicting a mental rather than physical state. Irony, sarcasm, and humor blend with pathos, suffering, and anger to express the bittersweet quality of a bicultural experience. Similar to Cisneros' work, Castillo's novel also depicts a coming of age story, not so much in the terms of young adolescence to adulthood but more in terms of adulthood incorporating self-recognition, maturity, and acceptance.

Scott Russell Sanders points out that one of the primary reasons we enjoy stories is "because they are a playground for language, an arena for exercising this extraordinary power" which reminds us of "the ambiguous potency in words, for creating or destroying, for binding or setting free" (54). This assertion implicitly describes Cisneros' and Castillo's major accomplishment. Both writers experiment with language and narrative techniques until they come across a mode of writing that better 
reflects their experience as contemporary bicultural, bilingual Chicanas; an experience that is far from conventional and refuses to be encased within orthodox narrative forms. Through their depictions of social environments, their search for identity, and their emotional release through writing, Cisneros and Castillo align themselves with other Chicana writers in their attempt to give voice to their struggles as well as their strengths. As readers we must accept the challenge set forth by writers such as Cisneros and Castillo. We can then join Hector Torres in concluding that "this calls for a vast redefinition of what it means to be an American and calls into question the narrow boundaries that confine the American literary canon" (143).

\section{WORKS CITED}

Alarçon, Norma. "Ana Castillo." Dictionary of Literary Biographies. Vol.122. Detroit: Gale Research, 1992. 62-65.

Castillo, Ana. The Mixquiahuala Letters. New York: Doubleday, 1992. Originally published by Bilingual Press, 1986.

Cisneros, Sandra. The House on Mango Street. New York: Vintage, 1989. Originally published by Arte Publico Press, 1983.

---, "Do You Know Me? I Wrote The House on Mango Street" Americas Review 15.2 (1987): 77-79.

De La Fuente, Patricia. "Ana Castillo." Dictionary of Literary Biography Vol. 122. Detroit: Gale Research, 1992. 62-65

Elias, Eduardo F. "Sandra Cisneros." Dictionary of Literary Biography Vol. 122. Detroit: Gale Research, 1992. 77-81.

Gonzalez-Berry, Erlinda. "The [Subversive] Mixquiahuala Letters: An Antidote for Self-Hate." Chicana (W)rites: On Word and Film. Berkeley: Third Woman P, 1995. 15-24.

Mesic, Penelope. "A Review of The House on Mango Street" Booklist 81.4 (1984): 281.

Sanders, Scott Russell. "The Most Human Art: Ten Reasons Why We'll Always Need a Good Story." Georgia Review Sept.-Oct. (1997): 5556. 


\section{Ethnic Studies Review Volume 26: 1}

Soto, Gary. "Sandra Cisneros." Contemporary Literary Criticism. Vol. 69. Detroit: Gale Research, 1992. 144.

Torres, Hector A. "Story, Telling, Voice: Narrative Authority in Ana Castillo's The Mixquiahuala Letters." Chicana (W)rites. 125-146.

TuSmith, Bonnie. All My Relatives: Community in Contemporary Ethnic American Literatures. Ann Arbor: U of Michigan P, 1994.

Wyatt, Jean. "On Not Being La Malinche: Border Negotiations of Gender in the Works of Sandra Cisneros." Studies in Women's Literature 14.2 (1995): 243-271. 